From the very moment of its introduction, the policy of Ukrainization gradually began to cover all aspects of the life of the Ukrainian people. As already emphasized, the first measures of Ukrainization were aimed at expanding the influence of the Ukrainian language, especially in the party and the government. One of the main tasks both in national politics and in the cultural construction of the 1920 's was the Ukrainization of various spheres of life. The Ukrainization of higher education was not entirely successful. Slightly better things were in secondary schools (colleges, pedagogical schools, three-year special courses).

Extensive results of Ukrainization have been achieved in the field of book printing. The Ukrainian press also experienced its revival during the period of Ukrainization. It should be noted that the process of Ukrainization in the literary and artistic fields was especially sharp and contradictory. Great difficulties had to be overcome on the way to the Ukrainianization of theaters. It should be noted that from the mid1920 s, considerable attention began to be paid to the Ukrainianization of libraries.

The Ukrainization of cinema was quite good at that time. It should be noted that significant successes have been achieved in the Ukrainianization of mass cultural and educational work.

The originality of this research is an attempt to objectively analyze the essence of the policy of Ukrainization, to pay attention to the peculiarities of its implementation in various spheres of public life, especially in rural areas.

Conclusion. The policy of Ukrainization enabled the Ukrainian people to realize themselves as a national community, to feel the importance of language, culture, and traditions as factors in the spiritual development of the nation. In literature and art, a new generation of national intelligentsia declared itself out loud, and interest in national traditions, folklore, and ethnography grew. Understanding the place and role of Ukraine in the USSR, in Europe, and in the world crystallized in the sharp controversy. As a result of the national reform, the social functions of the Ukrainian language increased, which became the language of education, court proceedings, and official office work. The language, which before the revolution was actually banned and did not have a developed socio-political vocabulary, approached the level of highly developed languages of the world. However, it did not cover all spheres of social and cultural life, in different regions the attitude to Ukrainization was different. The working language in the workplace remained Russian, and the processes of Ukrainization hardly affected the army. Even higher education institutions were Ukrainianized by only a third.

Key words: indigenization, Ukrainization, spheres of public life, personnel, state apparatus, public education, book printing, cultural life, cultural and educational development, Ukrainian language.

Одержано редакцією 25.03.2021

Прийнято до публікації 29.06.2021

УДК 94 (477) (092)

DOI: 10.31651/2076-5908-2021-1-81-87

NAKONECHNYJ Volodymyr,

$\mathrm{PhD}$ (History), Assistant Professor, Department of International

Relationships, Kyiv National

University of Culture and Arts, Orcid ID: 0000-0002-0386-2162

e-mail: nakonechniy.ua@gmail.com

\title{
UKRAINIAN-POLISH CONFLICT IN THE INTERWAR TIME AS COVERED BY THE «NASH LEMKO» NEWSPAPER
}

The article has analysed the situation of Ruthenians in interwar Poland according to the newspaper «Nash Lemko» ("Our Lemko»). It has identified the most difficult problems the Lemkos faced in the 1920s and 1930s. It has been concluded that the newspaper became a remarkable phenomenon of Ruthenian periodicals, which in the difficult conditions of the interwar period managed to unite the Lemkos with the ideas of preserving their own cultural identity and cultivating national unity.

Key words: international relations, "Our Lemko», Yulian Tarnovych, Lemko studies, Polish state.

Formulation of the problem. The issue of Ukrainian-Polish relations in the western Ukrainian lands in the interwar period twentieth century has been a popular subject of current 
historiographical findings. Ukrainian researchers keep investigating the roots of tragic events of inter-ethnic confrontation at that time. However, most of the studies usually focus on the Galician territory which was the main battleground against Polonization. Moreover, the resistance movement there was widespread and politically organized. Simultaneously, Ukrainian-inhabited Lemko territories, due to a certain distance from the ethnic centre and mountain specifics, suffered much more brutal denationalization of the local population and appalling infringement of their natural rights to elect their national cultural identity. Despite the scale of this issue, the researchers leave this problem largely unexplored.

The most informative source in covering this problem is Lemko periodicals' materials, which tirelessly recorded such manifestations of national lawlessness. The only Ruthenian newspaper of pro-Ukrainian orientation was «Nash Lemko» («Our Lemko»), published in the second half of the 1930s. From its columns, we learn about the planned and consistently implemented by representatives of the Polish administration many years of violence against Lemkos' national choice. Despite the constant confiscation of individual articles or even whole issues of the newspaper, the publication edited by Yulian Tarnovych waged a heroic, albeit unequal struggle for Lemkos' right to be Ukrainians, informing their readers about the forms and methods of denationalization of the westernmost ethnic group.

Analysis of recent research and publications. Given the uniqueness of «Our Lemko» as a historical source, it is repeatedly mentioned in Lemko studies' historiography [1]. However, there are currently no independent studies to elucidate the heuristic value of the journal's materials for reconstructing the specifics of Polish-Ukrainian relations in the Lemko region in the last prewar years. This fact determines the relevance of our research.

The purpose of the article is to clarify the specifics of the reflection of Ukrainian-Polish relations in the second half of the 1930s on the pages of «Our Lemko».

The presentation of the main material. According to «Our Lemko», the «guardianship» of the Polish state pervaded absolutely all spheres of life of the Ukrainian population in the mountains. However, the self-organization of public space was under specific scrutiny. Representatives of the Polish administration of all ranks - from village elders to police officers and representatives of the fiscal service - paid particular attention to those Ruthenians who professed Ukrainian national orientation. Thus, the marker of the last in officials' eyes was the fact of subscription to «Our Lemko». Although the newspaper was published completely legally and underwent meticulous censorship before it got into the hands of the reader, the subscribers of the publication were automatically included in the list of unreliable ones. Under various pretexts, officials visited those Lemkos and punished them for the smallest, often completely contrived offenses. Complaints about such visits often reached the editorial mail column, although mostly in abbreviated censored form. Since the file of «Our Lemko» in the library of the Ivan Franko National University of Lviv contains copies of the newspaper from the censorship committee, we sometimes have the opportunity to get a real picture of the Lemkos' appeals to their newspaper. Thus, in this regard, an anonymous reporter complained: «From the time I subscribed for «Our Lemko», I was punished. The police take special care of me. [...] All those who feel like Ukrainians are persecuted by the police, and the elder told me not to play in politics, because reading the newspaper «Our Lemko» is big politics in our country [...]. The life is bitter, full of denunciations, slanders, but we believe in a better future» $[2,3]$. While persecuting the subscribers of «Our Lemko», the Polish administration strongly encouraged the Ruthenians to read the Moscophile alternative to the publication - the newspaper «Lemko», published in Krynica.

«Prosvita» reading rooms, as leaders of national education and culture, particularly suffered from Polish administration's repressive policy in the Lemko region. Government officials tried at all costs to find reasons to close these centres of Ukrainian spirituality. Numerous accusations were targeted at people who rented their own houses for reading rooms, and when such evidence could not be found, police falsified «evidence» of dangerous public behaviour [3,9].

Those repressive measures went hand-in-hand with the purposeful intoxication of Lemkos with Polish and Moscophile propaganda, sweetened by various material incentives. For example, let us cite a letter from a resident of Ropytsia Ruska, Horlytsia district, about the establishment of the «Prosvita» reading room, which, in his words, «bothered the officials». After this event, a 
local teacher and a Polish teacher united the nationally inert representatives of the Lemko community and, contrary to the Ukrainians, founded the «Kyiko miodzierzy rusko-polskiej». Several «landlords, lured by sausage, sweets, cigarettes» also joined the denationalization centre. «Kettle tasted someone else's hay», an eyewitness remarked wittily. Marking those fellow villagers as «national werewolves», the contributor emphasized the danger of such public behaviour, which perpetuated the stereotype of a Lemko unconscious of his own identity. The witness of those events emotionally addressed the Ruthenian community: «Ropychany and Lemkos who sell their nationality, their faith, are either traitors like Judas or mad fish who hangs on a lord's hook. Come to your senses, find out who is your brother and who is your enemy. Do not indulge in other people's greed. Unite with your brothers and sisters. You don't need other people's gods. Look at other nations, everyone is uniting, and you?» [4, 8]. Certainly, according to the censor's copy of «Our Lemko», the mentioned quote was cut out.

Along with such facts of national confusion in the Ruthenian environment, «Our Lemko» spoke with particular respect about those citizens who did not betray their national conscience and did not succumb to threats from the Polish administration or the proposals of Moscophile agitators. The newspaper's columns were full of national optimism. They mobilized pro-Ukrainian sentiments among Ruthenians: «However, Ukrainians in the Lemko region will not lose hope, but continue to work on themselves, because they believe unwaveringly in better days - we honour them for this!» $[5,6]$.

While recklessly attacking the «Prosvita» reading rooms, Polish officials tried to oppose them with a kind of ideological alternative, Moscophile institutions, namely - reading rooms of the Kachkovsky Society [6, 2]. The contributors of «Our Lemko» argued that the Poles contribute to Moscophile propaganda in Ruthenian towns and villages and always help their struggle against the Ukrainians.

The most significant violence marked the Polish administration's actions in the field of education. According to its international obligations, the Polish state guaranteed cultural autonomy to its national minorities, primarily to the largest community - Ukrainians. However, in a short time, officials understood that without comprehensive influence on the school, it would be impossible to implement plans for the denationalization and, subsequently, the Polonization of the Ruthenian population. So, contrary to their international obligations, the Poles began the violent de-Ukrainization of the Lemko school. First of all, they tried to replace Ukrainian influences at school with Moscophile ones. According to the posts of «Our Lemko», Ukrainian primary school books were widely replaced by a Moscophile textbook. The book was written by the Moscophile Methodius Trokhanovsky and published in Lviv in 1933 by the Polish State Publishing House of School Books. The language of publication was so-called «Lemko conversation» - a Moscophile variant of the Lemko dialect. According to the correspondent of «Our Lemko», the «Judas work of the Krynytsia idols» was widely promoted by the Lviv school board, which was obliged to protect the national rights of Ruthenian children. The Lemkos were alarmed by that language choice. One of the newspaper's correspondents noted: «Today, every Lemko knows that his dialect can be used around his house, but the schooling must be conducted in a common Ukrainian literary language. [...] [Lemkos] seek Ukrainian literary language in school - the kind taught in all Ukrainian schools, because they are children of the same Mother! This is not a sentiment of some, this is the will of all Lemkos» [7, 3]. Given the tone of the message, the censor also severely edited this post.

Having lost the struggle for the language of primary education, the Polish school administration undertook to reform the curriculum of the Lemko school. Realizing the importance of religious education for preserving the national identity of the Ruthenians, education officials undertook a sharp reduction in the hours of teaching Greek Catholic catechism. Finding out the motivation of school inspectors, the correspondent of «Our Lemko» pointed out: «This is to the advantage of various «werewolves», Moscophile priests and Katsap teachers, who in recent years have sown black seeds of atheism and mistrust among the population, deliberately distributed Bolshevik pamphlets from various foreign publishing houses and read them to schoolchildren» $[8,3]$. This quote was censored as well. 
Another threat to the national schooling of the Lemkos was the forcible replacement of Ukrainian teachers by Poles. The Ukrainian professionals were appointed at schools with a predominant Polish contingent, while the Poles filled the positions at Ruthenian schools, which contributed to the denationalizing effect. These teachers, not knowing the native language of the local population, taught Lemko children in school in Polish, despite the law that provided the right for education in their native language $[9,8]$. That situation became the subject of many articles in the pages of «Our Lemko» that stated that «a Polish teacher is no different from a Polish policeman» $[10,4]$.

The Polish administration interfered into the sphere of the religious life of the Lemko community. Due to its tradition's specifics, the church has always been a reliable barrier against the Lemkos' polonization. The Polish state's religious policy aimed at imposing the stereotype that Lemkos were «Uniate Poles». Such propaganda became incredibly persistent in the spring of 1934 when a new papal administrator for the Lemko region was appointed in Rome. The editorial board of «Our Lemko» constantly emphasized that the Ruthenians are Greek Catholics and thus fundamentally different from the occupiers: «Allegations that all Lemko churches were built by Polish gentry were also untrue. The church chronicles clearly state that the Lemkos built churches for themselves together, and some churches were built by the village elders» $[11,4]$.

As it was impossible to change Lemkos' religious consciousness, Polish officials ensured that only priests loyal to the authorities administered at Ruthenian parishes. Otherwise, the nationally conscious pastors were forcibly transferred to villages with a predominant Polish population. In the newspaper columns, Lemkos complained that the Polish administration illegally removed socially active Ukrainian pastors from the parish. Instead, they were replaced by Moscophiles who tried to convert their parishioners to Russian Orthodoxy. Those priests and local officials forbade the population to read Ukrainian religious literature and pray in their native language. Describing this situation, the newspaper's contributors sadly pointed out: «Let us see, brothers, how beautiful Lemkiv region became; whoever takes a step towards the light of science is already heading towards prison...» $[12,8]$.

The Polish administration also paid close attention to the historical memory of the Lemkos. State officials made considerable efforts to reduce Ukrainian influence on forming the national self-consciousness of the Ruthenians. The Polish authorities applied every means in this struggle. They tolerated the propaganda of the Moscophiles and tried to present Lemkos as denationalized Poles. Therefore, officials' repression against the publications that shaped the Lemkos' Ukrainian optics of their past and future became more persistent. An eloquent illustration here is «Our Lemko», which suffered from constant censorship of its historical columns. Polish officials were particularly concerned about the commemoration of Western Ukrainians' short-lived statehood and their heroic defence of the Western Ukrainian People's Republic. Annual posts in «Our Lemko» on the occasion of the proclamation of unity on January 22, 1919, were constantly censored. One of the confiscated texts covered this heroic day for the Ukrainians of Zbruch: «On that memorable historical day, against all evil statements, the Ukrainian people proved their spiritual unity and inseparability. On that day, we told the world that we - Kuban and Dnipro Ukrainians, Volyniaks and Polishchuks and those from distant Podlasie and Kholmshchyna, Hutsuls, Boykos, Lemkos, Transcarpathians, Bukovynians and Bessarabians - are children of one common Mother Ukraine, united by one desire, with one faith, one idea» [13, 3].

Polish censors also tried to correct the canon of national heroes developed on the pages of «Our Lemko». Their attention was incredibly meticulous to the veneration of the Dnipro activists in the columns. Thus, when Mykhailo Hrushevsky died in November 1934, and the entire Western Ukrainian press responded to this painful event for the nation [14, 358-366], the censor intervened even in the content of the obituary published in the newspaper.

Despite the Polish administration's repressive policy towards «Our Lemko», the influence of the newspaper on the formation of the historical memory of Lemko-Ukrainians turned out to be considerable. For example, the censored letter of a Lemko-American to the newspaper's editorial office is evidence of admiration for «Our Lemko» and its Ukraine-centric memory policy. The reader noted: «[...] Thanks to the World War and the great Ukrainian Revolution, the words «Ukraine», «Ukrainian State», «Ukrainian people» shook me alive - I became free and aware of 
who I am; I know who made us slaves, who bowed their backs to intruders. We must remember that we are the sons of Mother Ukraine, brothers by blood with those who live in Greater Ukraine, Bukovina, Bessarabia, Galicia and Subcarpathian Ukraine! We, the great Nation, which no one will be able to destroy! Katsaps will perish for good, because all those who go against their brothers must perish! History teaches us that we all lived together in ancient times, had our own state, and we, Lemkos, created a powerful state with all the Ukrainian lands from the Carpathians to the Green Wedge - Ukraine» [15, 3].

The Polish state's economic policy regarding the Lemko territories caused bitter complaints in «Our Lemko» pages. Numerous authors of the newspaper drew attention to officials' barbaric approach to exploiting the region's natural resources and their unwillingness to invest in renewable projects. The situation of uncontrolled deforestation, which threatened the local population with natural disasters, became especially dangerous. For example, one of the censored posts described this problem as follows: «You used to be called Galician Siberia, my dear Lemkivshchyna. [...] The waters of Your healing springs heal others, Your children die in need, forests disappear from Your beautiful peaks, bridges are built of them on broken paths far away, while Your roads remain more and more devastated» $[16,3]$.

Along with repressive actions against Lemko's public initiatives of a pro-Ukrainian nature, the Polish administration interfered even in Ruthenians' private life, trying, for example, to regulate the style of their clothing. The newspaper's reporters have repeatedly expressed regret over the completely disenfranchising policies, aggressive towards the Lemko fashion of decorating their outfits with national colours. One of the newspaper authors talked about the Polish police's arbitrariness, who do not allow Lemkos to wear hats with blue and yellow tassels. He justifiably described such behaviour as savagery, comparing it to African colonisers' attitude towards the jungle's inhabitants $[17,5]$. A peculiar continuation of this theme was the local Polish press's sensation about the danger of the Lemkos borrowing the Dnipro embroidery technique because it testified the maturity of the Ruthenians' national choice [18, 3].

Highlighting the stubborn resistance of Ukrainian Lemkos to the policy of national oppression of the Polish administration, the editorial board of «Our Lemko» also offered a solution to such a dangerous situation for the public peace. According to Lemko intellectuals, such a solution could be national and cultural autonomy for the region. After all, the young Polish state was obliged to do so after taking control over Ukrainian territories after the Austro-Hungarian empire. However, any mentioning of autonomy in the columns of the newspaper suffered severe censorship. Even when «Our Lemko» published an article about Slovaks' struggle for autonomy within Czechoslovakia, the post was censored. The censors suspected that the article drew parallels with the Polish situation of oppression of national minorities.

Conclusions. The analysed posts of «Our Lemko» allow us to draw a relatively complete picture of the Polish administration's attitude to the Ukrainian population of Lemko. Its policy appals by its brutality and lawlessness - despite international commitments and simply a universal ethic of coexistence, the young state's officials have shown utter disregard for Ruthenians' cultural and social rights. On the other hand, the publishing team of "Our Lemko» and first of all, its editor-in-chiefYulian Tarnovych deserve the utmost respect. Despite censorship and police attacks, they carried out their essential work to cultivate a sense of ethnic identity and all-Ukrainian unity in the Ruthenian environment. Thanks to them, the Lemkos are still one of the most patriotic ethnographic groups of the Ukrainian people, even though the communities of many Central and Eastern European countries are divided and scattered around the world. We consider creating a generalising study of the Lemko periodicals of the interwar period to be a promising direction for further research on the topic.

\section{Список використаної літератури}

1. Тельвак В., Наконечний В. Становище русинської меншини в Другій Речі Посполитій за матеріалами газети «Наш лемко» / Віталій Тельвак, Володимир Наконечний // Русин. -2020. - № 61. - С. 166-182.

2. Гарні слова і наша дійсність // Наш лемко. - 1934. - Ч. 18. - С. 3.

3. Читальня загрожує публічній безпеці // Наш лемко. - 1936. - Ч. 22. - С. 9. 
4. Село Ропиця руська, пов. Горлиці // Наш лемко. - 1934. - Ч. 8. - С. 8.

5. Замикають читальні // Наш лемко. - 1935. - Ч. 7. - С. 6.

6. Як творяться читальні Качковського на Лемківщині? // Наш лемко. - 1934. - Ч. 6. - С. 2.

7. «Ми не хочемо букварів» // Наш лемко. - 1934. - Ч. 20. - С. 3.

8. Що далі буде? // Наш лемко. - 1934. - Ч. 21. - С. 3.

9. Біда з лемками... // Наш лемко. - 1936. - Ч. 14. - С. 8.

10. Дитина, як і життя, не дасть себе ошукати // Наш лемко. - 1935. - Ч. 24. - С. 4.

11. Лемко. В обороні історичної правди / Лемко // Наш лемко. - 1934. - Ч. 7. - С. 4.

12. Лемко. Навіть молитись не вільно / Лемко // Наш лемко. - 1936. - Ч. 4. - С. 8.

13. Галич Я. Сторінка нашого недавнього минулого / Ярослав Галич // Наш лемко. - 1936. - Ч. 3. - С. 3.

14. Тельвак В. Творча спадщина Михайла Грушевського в оцінках сучасників (кінець XIX 30-ті роки XX століття) / Віталій Тельвак. - Київ; Дрогобич: Вимір, 2008. - 494 с.

15. Лист з Америки // Наш лемко. - 1934. - Ч. 14. - С. 3.

16. Костаревич О. *****/ Остап Костаревич // Наш лемко. - 1934. - Ч. 1. - С. 3.

17. Лемко. Як у джунглях / Лемко // Наш лемко. - 1936. - Ч. 4. - С. 5.

18. Державна рація вимагає боротьби з вишивками на Лемківщині! // Наш лемко. - 1938. - Ч. 17. - С. 3.

\section{References}

1. Telvak V., \& Nakonechnyj V. (2020). The state of the Rusyn minority in the Second Commonwealth according to the materials of «Our Lemko» newspaper. Rusyn, 61, 166-182. (in Ukr.).

2. (1934). Good words and our reality. Our Lemko, 18, 3. (in Ukr.).

3. (1936). Reading room threatens public safety. Our Lemko, 22, 9. (in Ukr.).

4. (1934). The village of Ropitsa Ruska, the county of Gorlice. Our Lemko, 8, 8. (in Ukr.).

5. (1935). Closed reading rooms. Our Lemko, 7, 6. (in Ukr.).

6. (1934). How are the readers Kachkovsky in Lemkivshchyna? Our Lemko, 6, 2. (in Ukr.).

7. (1934). «We do not want the primers». Our Lemko, 20, 3. (in Ukr.).

8. (1934). What will happen next? Our Lemko, 21, 3. (in Ukr.).

9. (1936). Trouble with Lemkos ... Our Lemko, 14, 8. (in Ukr.).

10. (1935). The child, like life, will not be deluded. Our Lemko, 24, 4. (in Ukr.).

11. Lemko (1934). In the defense of historical truth. Our Lemko, 7, 4. (in Ukr.).

12. Lemko (1936). Even praying is not free. Our Lemko, 4, 8. (in Ukr.).

13. Halych, Ya. (1936). The page of our recent past. Our Lemko, 3, 3. (in Ukr.).

14. Telvak, V. (2008). Creative heritage of Mykhailo Hrushevsky in the estimations of his contemporaries (the end of the 19th and the 30th years of the 20th century). Kyiv-Drohobych. 494 s. (in Ukr.).

15. (1934). Letter from America. Our Lemko, 14, 3. (in Ukr.).

16. Kostarevych, O. (1934). *****. Our Lemko, 1, 3. (in Ukr.).

17. Lemko (1936). As in the jungle. Our Lemko, 4, 5. (in Ukr.).

18. (1938). Public interest requires fighting embroidery in Lemkivshchyna! Our Lemko, 17, 3. (in Ukr.).

НАКОНЕЧНИЙ Володимир Михайлович, кандидат історичних наук, доцент кафедри міжнародних відносин Київського національного університету культури і мистецтв,

e-mail: nakonechniy.ua@gmail.com

\section{УКРАЇНСЬКО-ПОЛЬСЬКЕ ПРОТИСТОЯННЯ В МІЖВОСННИЙ ЧАС У ВИСВІТЛЕННІ ГАЗЕТИ «НАШ ЛЕМКО»}

Постановка проблеми. Стаття присвячена з ясуванню становища лемків у польській державі міжвоєнного часу за дописами «Нашого лемка». Досліджено, що по сьогодні практично цілковито з поля зору істориків випадає політика польської держави стосовно заселених україниями лемківських теренів, котрі, внаслідок певної віддаленості від етнічного иентру та гірської специфіки, зазнавали значно брутальнішої денаціоналізації місиевого населення та безапеляційного ущемлення його природних прав на обрання власної культурної ідентифікації.

Мета статті полягає у з 'ясуванні специфіки відображення на шпальтах «Нашого лемка» українсько-польських взаємин в другій половині 1930-х рр.

Наукова новизна статті полягає у спробі комплексного аналізу образів польсько-украӥнського протистояння на сторінках газети «Наш лемко».

Висновки. Виявлено найбільш складні проблеми украӥнсько-польських взаємин в другій половині 1930-х років. Дописи «Нашого лемка» засвідчили, щьо специфічна «опіка» польської держави 
відчувалася абсолютно у всіх галузях життя українського населення гірських теренів. Найбільш дошкульною така увага була стосовно сфери самоорганізації громадського простору. Спеціальними об'єктами репресивної політики польської адміністрачії на Лемківщині стали читальні «Просвіти», як провідники національної освіти та культури. Найбільшою ж твалтовністю були позначені дї польської адміністрації в освітній сфері: всупереч взятим на себе міжнародним зобов 'язанням, поляки розпочали твалтовну деукраїнізацію лемківської школи. Прискіпливою з боку польської держави була й увага до історичної пам яті лемків. Чиновники докладали чималих зусиль, щоб зменшити украӥнські впливи на процеси формування національної самосвідомості русинів. Засобів у иій боротьбі польська влада не добирала - толерувала пропаганду москвофільського бачення минулого русинів чи намагалася показати їх як зденаціоналізованих поляків. Тож вповні очікуваними були репресії чиновників стосовно видань, котрі формували в лемків украйнську оптику їхнього минулого та майбутнього. Промовистою ілюстрачію тут став "Наш лемко», на чиїх шпальтах зустрічається найбільше чензорських викреслень саме в історичних рубриках. Поряд із репресивними акиіями стосовно лемківських громадських ініціатив проукрайнського характеру, польська адміністрачія нахабно втручалася навіть у приватне життя русинів, намагаючись, приміром, регламентувати стиль їхнього одягу. Доведено, що дописи «Намого лемка» дозволяють говорити про брутальне ставлення польської адміністрацї̈ до української меншості лемківських теренів. Тож викликає щиру повагу громадський чин колективу «Нашого лемка», щуо попри цензурні утиски та поліційні атаки, провадили свою важливу пращю над плеканням в русинському середовищі почуття етнічної самобутності та загальноукраїнської єдності.

Ключові слова: міжнародні відносини, «Нам лемко», Юліан Тарнович, лемкознавство, польська держава.

Одержано редакцією 23.04.2021

Прийнято до публікації 29.06.2021

УДК: 94(477)"198":37.091.212(581)

DOI: 10.31651/2076-5908-2021-1-87-97

\author{
КОВАЛЬКОВ Олександр Леонідович, \\ кандидат історичних наук, доцент \\ кафедри всесвітньої історії \\ Центральноукраїнського державного \\ педагогічного університету \\ iм. В. Винниченка, м. Кропивницький \\ Orcid ID: 0000-0003-2344-3050 \\ e-mail: KovalkovAlex@ukr.net
}

\title{
ПІДГОТОВКА АФГАНСЬКИХ СТУДЕНТІВ У НАВЧАЛЬНИХ ЗАКЛАДАХ УКРАЇНСЬКОЇ РСР У 1980-х рр. (на прикладі м. Кіровограда)
}

У статті досліджено підготовку громадян Демократичної республіки Афганістан у навчальних закладах Украӥнської РСР на прикладі м. Кіровограда. З'ясовано, що навчання в Радянському Союзі було важливим засобом виховання прорадянської генераиії афганської молод $i$, яка мала стати сочіальною опорою режиму Народно-демократичної партії Афганістану. В умовах «холодної війни» ие було складовою радянської політики «соиіалістичної орієнтації», спрямованої на перехід країн «третього світу» «від феодалізму до соиіалізму».

Ключові слова: Демократична республіка Афганістан, Украӥнська РСР, навчальні заклади, студенти, ідейно-політичне виховання.

Постановка проблеми. Упродовж десятиліття, від радянської військової інтервенції 25-27 грудня 1979 р. і до виведення «Об’єднаного контингенту радянських військ» 15 лютого 1989 р. Демократична республіка Афганістан (з 1987 р. - Республіка Афганістан) лише формально була суверенною державою. Вона перебувала під зовнішнім управлінням з Москви, була окупована 100-тис. радянським військовим контингентом, а реальне керівництво внутрішньою і зовнішньою політикою здійснювали тисячі радянських радників в усіх відомствах. Афганістан повністю залежав від СРСР у військово-політичній 